\title{
Shenandoah Watershed Study-Virginia Trout Stream Sensitivity Study (SWAS-VTSSS): stream water quality and hydrologic monitoring data for mid-Appalachian headwater streams
}

\author{
Ami L. Riscassi ${ }^{1}$, Todd Scanlon ${ }^{1}$, Suzanne Maben ${ }^{1}$, and Jim Galloway ${ }^{1}$ \\ ${ }^{1}$ University of Virginia
}

September 14, 2020

\begin{abstract}
The Shenandoah Watershed Study (established in 1979) and the Virginia Trout Stream Sensitivity Study (established in 1987) serve to increase understanding of hydrological and biogeochemical changes in western Virginia mountain streams that occur in response to acidic deposition and other ecosystem stressors. The SWAS-VTSSS program has evolved over its $40+$ year history to consist of a temporally robust and spatially stratified monitoring framework. Currently stream water is sampled bi-hourly during high-flow events at 3 sites and weekly at 4 sites within Shenandoah National Park (SHEN), and quarterly at 72 sites and on an approximately decadal frequency at $\sim 450$ sites within the wider western Virginia Appalachian region. Stream water is evaluated for $\mathrm{pH}$, acid neutralizing capacity (ANC), base cations (calcium, magnesium, sodium and potassium ion), acid anions (sulfate, nitrate and chloride), silica and ammonium, with a subset of samples evaluated for monomeric aluminum and dissolved organic carbon. Hourly stream discharge (4 sites) and in-situ measurements of conductivity, water and air temperature (3 sites) are also measured within SHEN. Here we provide an overview and timeline of the SWAS-VTSSS stream water monitoring program, summarize the field and laboratory methods, describe the water chemistry and hydrologic data sets, and document major watershed disturbances that have occurred during the program history. Website links and instructions are provided to access the stream chemistry and time-series monitoring data in open-access federal databases. The purpose of this publication is to promote awareness of these unique, long-term data sets for wider use in catchment studies. The water chemistry and hydrologic data can be used to investigate a wide range of biogeochemical research questions and provide key inputs for models of these headwater stream ecosystems. SWAS-VTSSS is an ongoing program and quality assured data sets are uploaded to the databases annually.
\end{abstract}

\section{Stream Monitoring Program}

The Shenandoah Watershed Study (SWAS) was founded by Dr. James Galloway, Dr. George Hornberger and Dr. Roger Pielke, as a joint program between the University of Virginia Environmental Sciences Department and Shenandoah National Park (SHEN), to assess watershed response to elevated acid deposition in the central Appalachian region. In 1979, SWAS established its first site in SHEN for weekly stream water sample collection and analysis of acid-base chemistry and stream discharge monitoring. The water chemistry monitoring program was spatially expanded in 1987 with the initiation of the Virginia Trout Stream Sensitivity Study (VTSSS) which, in collaboration with the Virginia Department of Game and Inland Fisheries (VDGIF) (recently renamed Virginia Department of Wildlife Resources, VDWR) and Trout Unlimited (TU) citizen volunteers, sampled the majority of native brook trout streams (Salvelinus fontinalis ) in Virginia. Results from the state-wide trout stream survey determined that the chemical response to acid deposition is primarily mediated by underlying bedrock (Sullivan, Webb, Snyder, Herlihy, \& Cosby, 2007; Webb, Cosby, Galloway, \& Hornberger, 1989). This point-in-time assessment informed a quarterly stream water sampling scheme for a geographically and geologically/chemically stratified subset of 72 sites (Webb et al., 2004). 
Further spatial and temporal expansion of the SWAS program occurred in the early 1990's in conjunction with the Fish in Sensitive Habitats (FISH) program (Bulger et al ., 1995), with 6 sites throughout SHEN sampled weekly by 1992. A subset of 3 weekly sites (hereafter 'intensive sites'), representing the range of sensitivity to acid deposition, were selected for streamflow monitoring and event-based sampling necessary to assess high-flow chemistry/episodic acidification (Eshleman, Miller Marshall, \& Webb, 1995; Hyer, Webb, \& Eshleman, 1995). In addition to maintaining the episodic, weekly and quarterly sampling until present, the SWAS program further advanced temporal monitoring in 2014/2015 with the incorporation of in-situ high-frequency air and water temperature and conductivity sensors at the 3 intensive sites. The state-wide VTSSS water quality survey (hereafter 'decadal survey') has been repeated in 2000, 2010, and is planned for 2021. A timeline of the SWAS-VTSSS program is presented in Figure 1.

\section{Overview of study area and watersheds}

The western Virginia study region includes the Valley and Ridge and the Blue Ridge physiographic provinces in the central Appalachian Mountains (Fig. 2). The region consists of parallel mountain ridges ranging from 750 to $1500 \mathrm{~m}$ above sea level. Forest cover is nearly complete and predominantly deciduous. The main bedrock types (classes) include igneous (mafic and felsic) rocks along the crest and eastern flank of the Blue Ridge province, with sedimentary (siliceous and argillaceous) rocks along the western flank of the Blue Ridge province and on the ridges of the Valley and Ridge Province (Dicken et al., 2005; Gathright, 1976; Sullivan et al., 2007). Most of the mountain stream watersheds in the region are small $\left(2-20 \mathrm{~km}^{2}\right)$ and the landscape is mostly protected or managed as public land, including SHEN and two U.S. Forest Service (USFS) National Forests (Fig. 2). A summary of the watershed size, dominant bedrock class, and land designation of the three distinct watershed sampling subsets (decadal, quarterly and weekly) are provided in Table 1.

\section{Field and Laboratory Methods}

Stream samples were collected manually for weekly, quarterly and decadal sampling. Episodic high-flow samples were collected bi-hourly by automated samplers when flows were equal to or above the $5 \%$ exceedance for the respective season (high-flow season: Nov 15-May 14 and low-flow season: May 15-Nov. 14). A subset of the collected automated event samples were analyzed: all samples on the rising hydrograph limb and $20 \%$ selected from the falling hydrograph limb. Samples were analyzed for acid neutralizing capacity (ANC), $\mathrm{pH}$, calcium ion $\left(\mathrm{Ca}^{2+}\right)$, magnesium ion $\left(\mathrm{Mg}^{2+}\right)$, potassium ion $\left(\mathrm{K}^{+}\right)$, sodium ion $\left(\mathrm{Na}^{+}\right)$ammonium ion $\left(\mathrm{NH}^{+}\right)$, sulfate ion $\left(\mathrm{SO}_{4}{ }^{2-}\right)$, nitrate ion $\left(\mathrm{NO}_{3}{ }^{-}\right)$, chloride ion $\left(\mathrm{Cl}^{-}\right)$, silica $\left(\mathrm{SiO}_{2}\right)$, and specific conductance. A subset of samples were also evaluated for total monomeric aluminum $\left(\mathrm{Al}_{\mathrm{TM}}\right)$, organic monomeric aluminum $\left(\mathrm{Al}_{\mathrm{OM}}\right)$ and dissolved organic carbon (DOC). During the analysis period, laboratory instrumentation was upgraded, and in some cases, methods changed. The analytical methods and correction factors used to align the older results with current instrumentation are available at https://swas.evsc.virginia.edu/POST/assets/docs/Methods.pdf.

Stream stage was measured hourly within a stilling well by an automated system and was verified by staff readings during weekly site visits. Routine manual discharge measurements were made with automated flow meters and salt dilution gaging methods (low flow conditions), and calculated with the Manning's equation (high flow conditions). Measured and calculated discharge were used to establish and maintain a rating curve, updated annually, for calculation of continuous discharge.

\section{Data Availability}

All water chemistry data are available through the Water Quality Portal (WQP, https://www.waterqualitydata.us/), a cooperative service sponsored by the U.S. Geological Survey, U.S. Environmental Protection Agency (U.S. EPA) and the National Water Quality Monitoring Council. SWAS-VTSSS data, collected as part of the long-term monitoring program, are organized by watershed land ownership into three Project IDs; SHEN_UVA_PRIMARY, USFS_UVA_PRIMARY, and OTHR_UVA_PRIMARY. Additional data collected and analyzed by the SWAS-VTSSS program, but not associated with the long-term monitoring sites (e.g. one-time synoptic sampling as part of the FISH program) are also available through the WQP. Time series data, including hourly discharge, air and water temperature and conductivity 
are available through the NPS Aquarius Web Portal (AWP) https://irma.nps.gov/aqwebportal/. Sites and associated data are accessed using identifier prefix SHEN_SWAS_SITEID (where SITEIDs are PAIN, PINE, STAN, and WOR1).

\section{Applications}

The SWAS-VTSSS program has been maintained, in large part, to evaluate the response of streams in the Appalachian region to ongoing decreases in acid deposition (Fig. 1) stemming from the implementation of the 1990 Clean Air Act Amendments (Riscassi, Scanlon, \& Galloway, 2019; Robison, Scanlon, Cosby, Webb, \& Galloway, 2013; Scanlon, Riscassi, \& Galloway, in review; Webb et al., 2004). Notably, a National Atmospheric Deposition Program (NADP) site, which measures analytes in precipitation, was established in 1981 in central SHEN (Fig. 2), providing the data necessary to reliably quantify and assess changes to watershed retention/export of individual ions through mass balance calculations (Robison et al., 2013) and to gain insight into the watershed characteristics responsible for regional differences in recovery (Eng \& Scanlon, in review). The physical and chemical data may also be used to 1) identify driving factors of biological trends (e.g. Blum, Kanno \& Letccher, 2018), 2) determine the most appropriate locations to investigate atmospheric pollutants, such as mercury, in both aqueous (e.g. Riscassi \& Scanlon, 2011) and biological (e.g. Eagles-Smith et al., 2020) environments, 3) calibrate and validate biogeochemical models for prediction of climate change impacts (e.g. Robison \& Scanlon, 2018), and 4) assesses the hydrologic and chemical response to watershed disturbances such as insect defoliations (e.g. Eshleman, Morgan, Webb, Deviney, \& Galloway, 1998), catastrophic flood events (e.g. Reinhardt \& Furman, 2008), and fire (e.g. Jensen, Scanlon, \& Riscassi, 2017) (Fig. 1).

\section{Acknowledgements}

The SWAS-VTSSS program has involved many individuals and various funding sources since inception. We acknowledge key personnel for their vital role in the establishment and maintenance of the program, including Dr. George Hornberger, Dr. Bernard "Jack" Cosby, Dr. Roger Pielke, Dr. Arthur Bulger, J. "Rick" Webb and Dr. Frank Deviney. Financial support for this program has been consistently provided by SHEN and the USEPA. In-kind support for quarterly sampling has been provided by the USFS, VDWR, and TU volunteers.

\section{References}

Blum AG, Kanno Y, Letcher BH. 2018. Seasonal streamflow extremes are key drivers of Brook Trout young-of-the-year abundance. Ecosphere9 (8): e02356 DOI: 10.1002/ecs2.2356

Bulger AJ, Dolloff CA, Cosby BJ, Eshleman KN, Webb JR, Galloway JN. 1995. The "Shenandoah National Park: Fish in sensitive habitats"' (SNP: fish) project. An integrated assessment of fish community responses to stream acidification. Water Air and Soil Pollution85 (2): 309-314 DOI: 10.1007/BF00476847

Dicken, CL., Nicholson, SW., Horton, JD., Kinney, SA., Gunther, G., Foose, MP., Mueller, JAL. 2005. Preliminary integrated geologic map databases for the United States: Delaware, Maryland, New York, Pennsylvania, and Virginia. USGS Open File Report 2005-1325.

Eagles-Smith CA, Willacker JJ, Nelson SJ, Flanagan Pritz CM, Krabbenhoft DP, Chen CY, Ackerman JT, Grant EHC, Pilliod DS. 2020. A National-Scale Assessment of Mercury Bioaccumulation in United States National Parks Using Dragonfly Larvae As Biosentinels through a Citizen-Science Framework. Environmental Science 63 Technology 54 (14): 8779-8790 DOI: 10.1021/acs.est.0c01255

Eng, LE, Scanlon, TM. (in review). Comparison of Northeastern and Southeastern U.S. Watershed Response to the Declines in Atmospheric Sulfur Deposition. Atmospheric Environment.

Eshleman KN, Miller Marshall LM, Webb JR. 1995. Long-term changes in episodic acidification of streams in Shenandoah National Park, Virginia (USA). Water Air and Soil Pollution 85 (2): 517-522 DOI: 10.1007/BF00476881 
Eshleman KN, Morgan RP, Webb JR, Deviney FA, Galloway JN. 1998. Temporal patterns of nitrogen leakage from mid-Appalachian forested watersheds: Role of insect defoliation. Water Resources Research 34(8): 2005-2016 DOI: 10.1029/98WR01198

Gathright, T.M. 1976. Geology of the Shenandoah National Park, Virginia, Bull. Va. Division of Mineral Resources, 86, 1976.

Hyer KE, Webb JR, Eshleman KN. 1995. Episodic acidification of three streams in Shenandoah National Park, Virginia, USA. Water Air and Soil Pollution 85 (2): 523-528 DOI: $10.1007 /$ BF00476882

Jensen AM, Scanlon TM, Riscassi AL. 2017. Emerging investigator series: the effect of wildfire on streamwater mercury and organic carbon in a forested watershed in the southeastern United States.Environmental Science-Processes 83 Impacts 19 (12): 1505-1517 DOI: 10.1039/c7em00419b

Reinhardt KS, Furman T. 2008. Effects of catastrophic flooding on stream biogeochemistry in a headwater stream in Shenandoah National Park, USA.Hydrological Processes 22 (18): 3759-3771 DOI: 10.1002/hyp.6980

Riscassi A, Scanlon T, Galloway J. 2019. Stream geochemical response to reductions in acid deposition in headwater streams: Chronic versus episodic acidification recovery. Hydrological Processes33 (4): 512-526 DOI: 10.1002/hyp.13349

Riscassi AL, Scanlon TM. 2011. Controls on stream water dissolved mercury in three mid-Appalachian forested headwater catchments. Water Resources Research 47 : W12512 DOI: 10.1029/2011WR010977

Robison AL, Scanlon TM. 2018. Climate Change to Offset Improvements in Watershed Acid-Base Status Provided by Clean Air Act and Amendments: A Model Application in Shenandoah National Park, Virginia. Journal of Geophysical Research-Biogeosciences 123 (9): 2863-2877 DOI: 10.1029/2018JG004519

Robison AL, Scanlon TM, Cosby BJ, Webb JR, Galloway JN. 2013. Roles of sulfate adsorption and base cation supply in controlling the chemical response of streams of western Virginia to reduced acid deposition.Biogeochemistry 116 (1-3): 119-130 DOI: 10.1007/s10533-013-9921-6

Scanlon, T M, Riscassi, AL, Galloway, J N (in review). Observed Changes in Chronic and Episodic Acidification in Virginia Mountain Streams in Response to the Clean Air Act and Amendments. Atmospheric Environment.

Sullivan TJ, Webb JR, Snyder KU, Herlihy AT, Cosby BJ. 2007. Spatial distribution of acid-sensitive and acid-impacted streams in relation to watershed features in the Southern Appalachian Mountains. Water Air and Soil Pollution 182 (1-4): 57-71 DOI: 10.1007/s11270-006-9320-x

Webb J, Cosby B, Galloway J, Hornberger G. 1989. Acidification of Native Brook Trout Streams in Virginia. Water Resources Research 25 (6): 1367-1377 DOI: 10.1029/WR025i006p01367

Webb JR, Cosby BJ, Deviney FA, Galloway JN, Maben SW, Bulger AJ. 2004. Are brook trout streams in western Virginia and Shenandoah National Park recovering from acidification? Environmental Science $\mathcal{E}$ Technology 38 (15): 4091-4096 DOI: 10.1021/es049958a

\begin{tabular}{|c|c|c|c|c|c|c|c|c|c|c|c|c|c|}
\hline \multirow[b]{2}{*}{$\begin{array}{l}\text { Sampling } \\
\text { Frequency }\end{array}$} & \multirow[b]{2}{*}{$\begin{array}{c}\# \\
\text { sites }\end{array}$} & \multicolumn{4}{|c|}{ Watershed Area, $\mathrm{km}^{2}$} & \multicolumn{5}{|c|}{ Dominant Bedrock Class ${ }^{\dagger}, \%$ of watersheds } & \multicolumn{3}{|c|}{$\begin{array}{l}\text { Majority land ownership, \% of } \\
\text { watersheds }\end{array}$} \\
\hline & & mean & stdev & $\min$ & $\max$ & $\begin{array}{l}\text { Mafic } \\
\text { (e.g. } \\
\text { basalt) }\end{array}$ & $\begin{array}{c}\text { Felsic } \\
\text { (e.g. } \\
\text { granite) }\end{array}$ & $\begin{array}{l}\text { Argillaceous }^{\ddagger} \\
\text { (e.g. shale) }\end{array}$ & $\begin{array}{l}\text { Siliceous }^{*} \\
\text { (e.g. } \\
\text { sandstone) }\end{array}$ & Carbonate & NPS & USFS & OTHER \\
\hline $\begin{array}{c}\text { Decadal - } \\
2010 \\
\text { (VTSSS) }\end{array}$ & 457 & 6.6 & 6.7 & 0.1 & 78.2 & $\begin{array}{c}6 \% \\
\text { (29 sites) }\end{array}$ & $\begin{array}{c}23 \% \\
\text { (104 sites) }\end{array}$ & $\begin{array}{c}23 \% \\
(106 \text { sites })\end{array}$ & $\begin{array}{c}47 \% \\
\text { (215 sites) }\end{array}$ & $\begin{array}{c}1 \% \\
\text { (3 sites) }\end{array}$ & $\begin{array}{c}14 \% \\
(65 \text { sites })\end{array}$ & $\begin{array}{c}67 \% \\
(305 \text { sites) }\end{array}$ & $\begin{array}{c}19 \% \\
\text { (87 sites) }\end{array}$ \\
\hline $\begin{array}{l}\text { Quarterly } \\
\text { (VTSSS) }\end{array}$ & 72 & 6.8 & 4.9 & 1.4 & 23.7 & $\begin{array}{c}7 \% \\
(5 \text { sites })\end{array}$ & $\begin{array}{c}22 \% \\
\text { (16 sites) }\end{array}$ & $\begin{array}{c}13 \% \\
\text { (9 sites) }\end{array}$ & $\begin{array}{c}58 \% \\
\text { (42 sites) }\end{array}$ & - & $\begin{array}{c}21 \% \\
\text { (15 sites) }\end{array}$ & $\begin{array}{c}67 \% \\
\text { (48 sites) }\end{array}$ & $\begin{array}{c}12 \% \\
\text { (9 sites) }\end{array}$ \\
\hline $\begin{array}{l}\text { Weekly } \\
\text { (SWAS) }\end{array}$ & 4 & 10.2 & 3.5 & 5.1 & 12.6 & $\begin{array}{c}25 \% \\
\text { (1 site) }\end{array}$ & $\begin{array}{c}25 \% \\
\text { (1 site) }\end{array}$ & - & $\begin{array}{c}50 \% \\
\text { (2 sites) }\end{array}$ & - & $\begin{array}{c}100 \% \\
\text { (4 sites) }\end{array}$ & - & - \\
\hline
\end{tabular}

† bedrock classification based on Dicken et al., 2005

‡Siliceous and Argillaceous classes were grouped into a single Siliciclastic class within Robison et al., 2013, and Scanlon et al., in review 

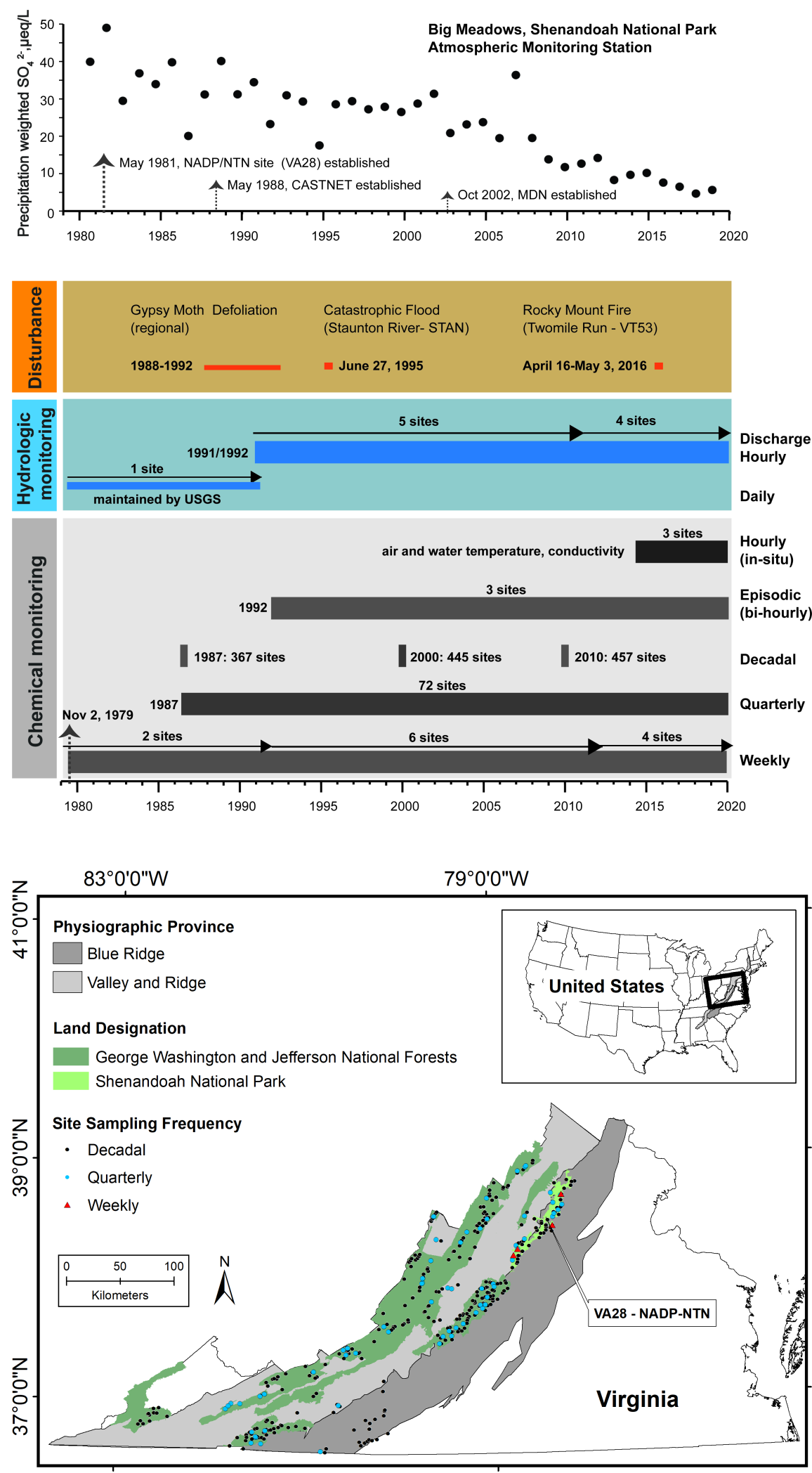